\title{
Mass production, fermentation, formulation of Pseudomonas putida for controlling of die back and phomopsis diseases on grapevine
}

\author{
Wafaa M. Haggag ${ }^{1 *}$, Malaka A. E. Saleh${ }^{2}$, Inas Mostafa ${ }^{3}$, Noran Adel ${ }^{1}$ \\ ${ }^{1}$ Pathology Department, National Research Centre, Dokki, Egypt \\ ${ }^{2}$ Pomology Department, National Research Centre, Dokki, Egypt \\ ${ }^{3}$ Biotechnology and Genetic Engineering Unit, Dokki, Egypt \\ Email: *wafaa haggag@yahoo.com
}

Received 16 March 2013; revised 1 May 2013; accepted 16 May 2013

Copyright (C) 2013 Wafaa M. Haggag et al. This is an open access article distributed under the Creative Commons Attribution License, which permits unrestricted use, distribution, and reproduction in any medium, provided the original work is properly cited.

\begin{abstract}
The export oriented agricultural and horticultural crops depends on the export of residue free produce and has created a great potential and demand for the incorporation of biopesticides in crop protection. PGPR with wide scope for commercialization includes Pseudomonas putida. Pseudomonas putida was effective in reducing die back caused by a fungus Botryodiplodia theobromae and phomopsis or arm death, caused by a fungus, Phomopsis viticola of grapevine in vitro and in vivo. Pseudomonas putida showed optimum Siderophore pseudobactin production at $72 \mathrm{~h}$, and growth peak at $120 \mathrm{~h}$. glycerol as a source of carbon and yeast as a source of nitrogen Pseudomonas putida was formulated using polysaccharide dextran starch, which led to the elongation of conservation and the effectiveness of the biofungicide. Pseudomonas putida was very effective as biocontrol agents to reduce the die back and phomopsis diseases on grapevine. The obtained results showed that both bacterial treatments significantly increased the growth parameters as well as fruits dry weights and yield of grapevine.
\end{abstract}

Keywords: Die Back; Phomopsis Diseases; Grapevine and Pseudomonas putida

\section{INTRODUCTION}

Foliar diseases caused by fungi result in millions of dollars damage to horticulture crops and crop products each year in Egypt. Grapevine (Vitis vinifera) is the major temperate fruit in term of world quantity produced (63

\footnotetext{
${ }^{*}$ Corresponding author.
}

million tones, FAO, 2003). Egypt is growing in importance as grape-producing country. Diseases limit the production of grapevine. Dieback and dead arm are degenerative diseases of mature vines which threaten the sustainability of premium Egyptian vineyards. Grape Eutypa die-back caused by Botryodiplodia theobromae Pat., is one of the most destructive woody tissue diseases found in commercial grape production $[1,2]$. The fungi grow slowly in the wood and foliar symptoms are not evident until several years after infection [3]. Therefore, the fungi are well-established in the vine before diseases symptoms are visible. Some authors also report Botryosphaeriaceae as associated with foliar chlorosis and necrosis, or with fruit rot symptoms [2,4]. Phomopsis viticola, the cause of a grapevine disease known worldwide as phomopsis cane and leaf spot $[5,6]$. Crop loss is generally through girdling of shoots and weakening and cracking of canes, which consequently lowers productivity of vines. The most efficient way to control eutypa dieback is the use of good cultural practices. Eutypa dieback is viable in the field for many years [7].

Control of fungal pathogens is based on the use of agronomic practices and pesticides, but widespread application of chemicals inundates the agro-eco systems with toxic compounds that affect the balance of the natural food chain. Biocontrol technologies have gained momentum in disease control of crop plants in recent times as these technologies not only minimize or replace the usage of harmful chemical pesticides but also found to be cheaper and efficient in certain disease control programmes. Most sustainable and environmentally acceptable control may be achieved using biocontrol agents (BCAs) $[8,9]$. Though bio-control with PGPR is an acceptable green approach, the proportion of registration of biocontrol agents for commercial availability is very 
slow. This differential effectiveness is clearly illustrated by results from three PGPR strains, Pseudomonas putida, in different plant-pathogen systems. Interested in the pseudomonads has increased recently because of the possible use of siderophores as biopesticides [10]. Bacterial determinants involved in the elicitation of ISR bythese strains are the fluorescent siderophore pseudobactin, the outer membrane lipopolysaccharide (LPS), and the flagella of $P$. putida WCS358 [11]; the pseudobactin, other iron-regulated metabolites and LPS of $P$. putida WCS374, and the LPS and iron-regulated metabolites other than pseudobactin for WCS417 $[12,13]$. The major aspects of successful biological technologies include the establishment of product, formulation and delivery system for microorganism that enable them for efficient disease control. The present work was focused on bioprocess optimization for high cell mass and siderophoreproduction of Pseudomonas putida in semi-industrial scale for biofungicide application against die back and phomopsis diseases on grapevine.

\section{MATERIALS AND METHODS}

\subsection{Collection of Samples, Isolation and Culturing}

In field surveys of vineyards conducted at in 10 vine-growing in Noubaria areas of Bohera governorate, 2009, we obtained 10 diseased wood samples from vines showing bleached canes with longitudinal lesions, dead spurs and perennial cankers. These samples were surface-sterilised with $2 \%$ sodium hypochlorite for $2 \mathrm{~min}$, rinsed twice with sterile distilled water for $2 \mathrm{~min}$, and then dried in laminar flow for $10 \mathrm{~min}$. and plated onto $90 \mathrm{~mm}$ Petri dishes containing potato dextrose agar (PDA) and streptomycin sulphate $\left(50 \mu \mathrm{g} \cdot \mathrm{mL}^{-1}\right)$ (PDA-Strep). PDA-Strep plates were incubated in the dark at $25^{\circ} \mathrm{C}$ until fungal colonies were observed. In order to obtain pure fungal cultures, hyphal tips from colony margins were transferred to fresh PDA plates and incubated under near ultra-violet (NUV) light in $12 \mathrm{~h}$ light-dark cycles for one to three weeks to stimulate sporulation.

\subsection{Isolation of Pseudomonas putida and Antagonists Study}

Isolation of $P$. putida was previously isolated from phyllosphere of grapevine fields in Ismailia governorate using King's B medium. After incubation, the individual colonies were picked up with sterile loop and transferred to fresh King's B slants and the pure cultures so obtained were stored in refrigerator at $40^{\circ} \mathrm{C}$ for further use. Pure cultures of the selected isolates were streaked on King's B agar Petri plates separately for colony development. The individual colonies were examined for shape, size, structure of colonies and pigmentation.
The antagonistic activity of $P$. putida against B. theobromae and $P$. viticola was tested by dual culture technique. Bacterial isolates were streaked at one side of Petri dish (one $\mathrm{cm}$ away from the edge) containing PDA. $9 \mathrm{~mm}$ mycelial disc from seven days old PDA culture of B. theobromae and P. viticola were placed at the opposite side of Petri dishes perpendicular to the bacterial streak and incubated at $28^{\circ} \mathrm{C} \pm 2^{\circ} \mathrm{C}$ for $5-7$ days. Petri dishes inoculated with fungal discs alone served as control. Three replications were maintained for each isolate. Observation on width of inhibition zone and mycelia growth of test pathogen was recorded.

\subsection{Bacteria Optimization and Production}

\subsubsection{Cultivation of the Bacteria producing Microorganisms Maintenance of Cultures}

The Bacterialstrain mentioned above was grown and maintained on the Difco nutrient agar medium The $\mathrm{pH}$ was adjusted at $7.0-7.2$ using $2 \mathrm{~N}\left(\mathrm{NaOH}, \mathrm{HCl}\right.$ and $\left.\mathrm{H}_{2} \mathrm{SO}_{4}\right)$ solution. The ingredients of this medium were dissolved in fresh distilled water, digested at about $95^{\circ} \mathrm{C}-100^{\circ} \mathrm{C}$ on a water bath and dispensed in test tubes (about $5 \mathrm{ml} /$ test tube). The latter were plugged and sterilized by autoclaving at about $121^{\circ} \mathrm{C}$ and 1.5 atmospheric pressures for 15 minutes. The tubes were left to attain room temperature and then inoculated with the Bacillus strains under aseptic conditions. The inoculated slants were incubated at $35^{\circ} \mathrm{C}-37^{\circ} \mathrm{C}$ for 48 hours then stored in refrigerator until used.

\subsubsection{Production Conditions}

Unless otherwise mentioned, the production process was carried out in $250 \mathrm{ml}$ Erlenmeyer flasks containing $50 \mathrm{ml}$ aliquots of the fermentation medium under test conditions. The flasks were inoculated with the seed culture at $1 \% \mathrm{v} / \mathrm{v}$ and incubated under shaking conditions (150 rpm) and at $30^{\circ} \mathrm{C}$ for 2 days. At the end of the specified incubation period, the fermentation broth was sampled for determination of biomass (optical density and dry weight), residual substrate and inhibition zone.

\subsubsection{Determination of Bacterial Growth}

\subsubsection{Determination of Biomass by Optical Density} Measurement

The absorbance of cultures was measured at $600 \mathrm{~nm}$, using Spectrophotometer (UV/V spectrophotometer, Labomed-Inc UV-vis double beam PC 8 scanning autocelIUVD-3200) and cell free medium used as blank. The samples were diluted with the cell free medium to avoid the inaccuracy with the absorbance readings above one.

\subsubsection{Determination of Biomass by Cell Dry Weight} The cells from inoculated flasks, each containing $50 \mathrm{ml}$ 
fermentation medium, were centrifuged using a cooling centrifuge ((Biofuge. Primo R) Heraeus-Germany) in preweighted centrifugation tubes of $50 \mathrm{ml}$ volume (Falcon USA) at $6000 \mathrm{rpm}$ for 10 minutes. The cell precipitates were collected, washed with sterile $0.9 \%$ saline solution and re-centrifuged. The supernatants were discarded and the centrifugation tubes were dried in an oven (Drying oven LabTechLDO-080F, Korea) at $100^{\circ} \mathrm{C}$ till constant weights were obtained. The weight of the dried cells was measured by calculation of the difference between the weight of centrifugation tubes before and after dryness.

\subsubsection{Production of Siderophore from the Medium}

The spent culture fluid was separated from the cells by centrifugation at $7000 \mathrm{rpm}$ for $15 \mathrm{~min}$. The supernatant was concentrated to one fifth of the original volume by the flash evaporation at $45^{\circ} \mathrm{C}$. Catechol type phenolates were extracted with ethyl acetate from the culture supernatant twice with an equal volume of solvent at $\mathrm{pH}$ 2.0. The ethyl acetate layer was removed and evaporated to dryness and the residues were dissolved in a minimum quantity of distilled water, while hydroxamate types were measured from the untreated culture supernatant.

\subsubsection{Effect of Initial pH}

Erlenmeyer flasks containing aliquots of glucose-free medium were prepared at different $\mathrm{pH}$ values of 5.5, 6.0, 6.5, $6.8,7.0,7.2,7.5,8.0,8.5 \& 9.0$ by using $2 \mathrm{~N}(\mathrm{NaOH}, \mathrm{HCl}$ and $\mathrm{H}_{2} \mathrm{SO}_{4}$ ). The flasks were autoclaved at $121^{\circ} \mathrm{C}$ for 15 min. After cooling the flasks, glucose was incorporated to its original concentration (1\%). Glucose addition altered the pre-adjusted $\mathrm{pH}$ by no more than \pm 0.04 . Then, the flasks were inoculated and incubated at $30^{\circ} \mathrm{C}$ and 150 $\mathrm{rpm}$. At the end of the incubation period, samples were removed determination of biomass (optical density and dry weight), residual substrate and inhibition zone. The $\mathrm{pH}$ values were measured by (PH meter HANNA instruments $\mathrm{HI} 9321$ micro procees or $\mathrm{pH}$ meter) $\mathrm{pH}$ meter, triplicates were used for each $\mathrm{pH}$ value.

\subsubsection{Effect of Different Carbon Sources}

The effect of replacing glucose in the cultivated medium with other tested carbon sources on antibiotic production was investigated in Bacillus isolate. The tested carbon source was added at a concentration equivalent in carbon content to that of glucose $(10 \mathrm{~g} / \mathrm{L})$. The tested carbon sources were (D-glucose, D-fructose, sucrose, maltose, lactose, galactose, $\mathrm{D}(+)$ - mannose, raffinose, glycerol, starch, cellulose, treated molasses and none treated). Erlenmeyer flasks $(250 \mathrm{ml})$ containing $50 \mathrm{ml}$ of the medium devoid of its own carbon source and containing the equivalent amount of other carbon sources were prepared, inoculated and incubated as described in (1.2). At the end of the incubation period, samples were removed for determination of biomass (optical density and dry weight), residual substrate and inhibition zone.

\subsubsection{Effect of Variable Concentrations of the Selected Carbon Source}

Flasks $(250 \mathrm{ml})$ with $50 \mathrm{ml}$ aliquots of the medium containing different concentrations of the carbon source that showed promising results were prepared. These carbon source was D-glucose $(1 \%, 1.5 \%, 2 \%, 2.5 \%, 3 \%, 3.5 \%$, $4 \%, 5 \% \mathrm{w} / \mathrm{v})$. The flasks were terminally sterilized, inoculated and incubated as described in (1.2). At the end of the incubation period, samples were removed for determination of biomass (optical density and dry weight), residual substrate and inhibition zone.

\subsubsection{Effect of Different Nitrogen Sources}

This was studied by replacing sodium nitrate of medium with other tested nitrogen sources. The tested nitrogen source was added at a concentration equivalent in nitrogen content to that of sodium nitrate $(2.5 \mathrm{~g} / \mathrm{L})$. The studied nitrogen sources were classified into organic (urea, yeast extract, peptone, tryptone and corn steep liquor) and inorganic sources (sodium nitrate, potassium nitrate, ammonium nitrate, ammonium chloride, ammonium sulfate, Di Ammonium hydrogen phosphate). Erlenmeyer flasks $(250 \mathrm{ml})$ containing $50 \mathrm{ml}$ aliquots of MSM devoid of its own nitrogen source and containing the equivalent amount of other nitrogen sources were prepared, inoculated and incubated as described in (1.2). In case of urea, a stock solution was prepared; filter sterilized $(0.22 \mu \mathrm{m})$ and then an aliquot containing the required amount of urea was incorporated aseptically. The nitrogen content in CSL, as known from literature, was $3.3 \% \mathrm{w} / \mathrm{w}$, so nitrogen molar ratio for CSL was 0.033 . However, for yeast extract, peptone, tryptone; the nitrogen ratio was $0.098,0.14$ and 0.127 respectively, as claimed by the manufacturers. At the end of the incubation period, samples were removed for determination of biomass (optical density and dry weight), residual substrate and inhibition zone.

\subsection{Formulation}

The formulation of P. putida was prepared using $0.01 \%$ as glycerol oil, soybean oil, polysaccharide as methylcellulose (CMC), D-glucose at $0.1 \%$ concentration, starch dextran. The liquid formulations were evaluated initially during storage periods at $4^{\circ} \mathrm{C}$ temperature. The percent of survival bacteria were measured during three months. Survival of $P$. putida in the formulations was assessed at 30 day intervals by a dilution plate method [14]. There were three replications for each analysis. 


\subsection{Field Experiments}

The efficacies of wettable powder formulation of BCAs against grape diseases under natural conditions were conducted during 2011 and 2012 seasons. Three experiments were performed in vineyard at Kalubia governorate (clay soil) on eight years old, Flam cultivar, Ismailia governorate (sand loamy soil) on ten years old, Flam cultivar and in Khatate, Sharkia Governorate (sandy loam soil) on ten years old, Flam cultivar. The vines were placed at $1.5 \mathrm{~m}$ (between vines in the row) $\times 2.75 \mathrm{~m}$ (between rows). The vineyard experiments were arranged in a randomized complete block design with four replications for each variant, four vines for each replicate.

Treatments were applied twice at 20-d intervals on grape vines in on-year. Treatments were applied two weeks before bloom at first of March. The BCAs were sprayed by using a knapsack sprayer. Vines were sprayed till run-off with approximately $2 \mathrm{~L}$ of spray solution per vine. Treatments were assigned in a randomized complete block design. Vines sprayed with water were served as a check treatment. Plots consisting of 10 grape vines were replicated four times. Forty-two grapevines (six treatments and untreated control, each replicated six times), nearly uniform in vigour, were randomly selected. Irrigation, fertilization and other cultural practices were carried out as recommended.

\subsection{Phomopsis and Die Back Diseases}

Phomopsis and die back diseases were conducted at two stage of growth period included field nurseries and in mature tree by examining 10 branches. Graftlings were placed in boxes ( 300 per box) filled with moist sawdust for standard cold callusing.

\subsection{Yield}

The total yield $(\mathrm{Kg})$ per vine was recorded. At harvest date (the $1^{\text {st }}$ week of June) some measuring of vegetative growth and the yield per vine was recorded in the term of weight (in $\mathrm{kg}$ ). Three bunches of each replicate were taken and immediately transport to the laboratory to determine the various fruit characteristics.

Measurements of vegetative growth characters: Cane length $(\mathrm{cm})$, Cane thickness $(\mathrm{cm})$, Number of leaves/ shoot and leaf area $\left(\mathrm{cm}^{2}\right)$.

Quality assessments: Major physical characteristics of mature "Flam" berries: Major chemical characteristics of mature berries: Total Soluble Solids Percentage (TSS\%) and Total.

\subsection{Statistical Analysis}

For data analysis, the statistical computer application package SPSS 10.0 will be employed. Data will be subjected to analysis of variance (ANOVA) and the means will be compared for significance using Duncan's Multiple Range Test (DMRT; $P=0.05$ ).

\section{RESULTS AND DISCUSSION}

\subsection{Microorganisms}

Botryodiplodia theobromae and Phomopsis viticola were isolated from all tissue types sampled in this survey. Cultures were grown on Potato Dextrose agar.

$P$. putida was isolated from the phyllosphere of grapevine grown in Noubaria used in this study. Isolate was found to be very effective against $B$. theobromae and $P$. viticola (Figure 1). After five days incubation, strain $P$. putida inhibited growth of $B$. theobromae and P. viticola. Hence, this isolate was further used.

\subsection{Bacteria Optimization and Production}

The time course for dry weight differs slightly from the previous observations, as it increases till $48 \mathrm{hrs}$ then remains constant for $12 \mathrm{hrs}$ and starts increasing again during the remaining incubation time. In the inhibition zone curve, Phomopsis and Botryodiplodia follow the same pattern whereas the inhibition zone increases with incubation period till it reaches its maximum at $48 \mathrm{hrs}$ in the case of Phomopsis then remains constant for $12 \mathrm{hrs}$ and starts decreasing. While in the case of Botryodiplodia we notice that the inhibition zone is maximum at 48 hrs then decreases for the remaining time (Figure 2).

Production of siderophore increased radically from the beginning of incubation time till $72 \mathrm{hrs}$ then decreased. During optimization of various parameters from all these, we deduce that the maximum incubation period for the growth of $P$. putida is $48 \mathrm{hrs}$. The ability of Pseudomonas to grow and to produce siderophores is dependent on the iron content and the type of carbon sources in the medium. Under conditions of low-iron concentration the Pseudomonas isolates studied produced yellow-green fluorescent iron-binding peptide siderophores and the biosynthesis of this siderophores was affected by several different environmental parameters.

From the experimental results it was noticed that by using different types of carbon source for the growth of $P$. putida, the dry weight concentration was almost maximum with glycerol as a carbon source (Figure 3). Also, the productions of siderophore were maximum with glycerol. The zone inhibition of Botryodiplodia, and Phomopsis were maximum by using glycerol. So, the glycerol was chosen as an optimum carbon sources for P. putida.

By using different concentration of glycerol for the growth of $P$. putida, the dry weight concentration increased gradually with increasing the glycerol. Also, the production of siderophore increased by increasing the glycerol concentration till $1.5 \% \mathrm{v} / \mathrm{v}$ then decreased again. 


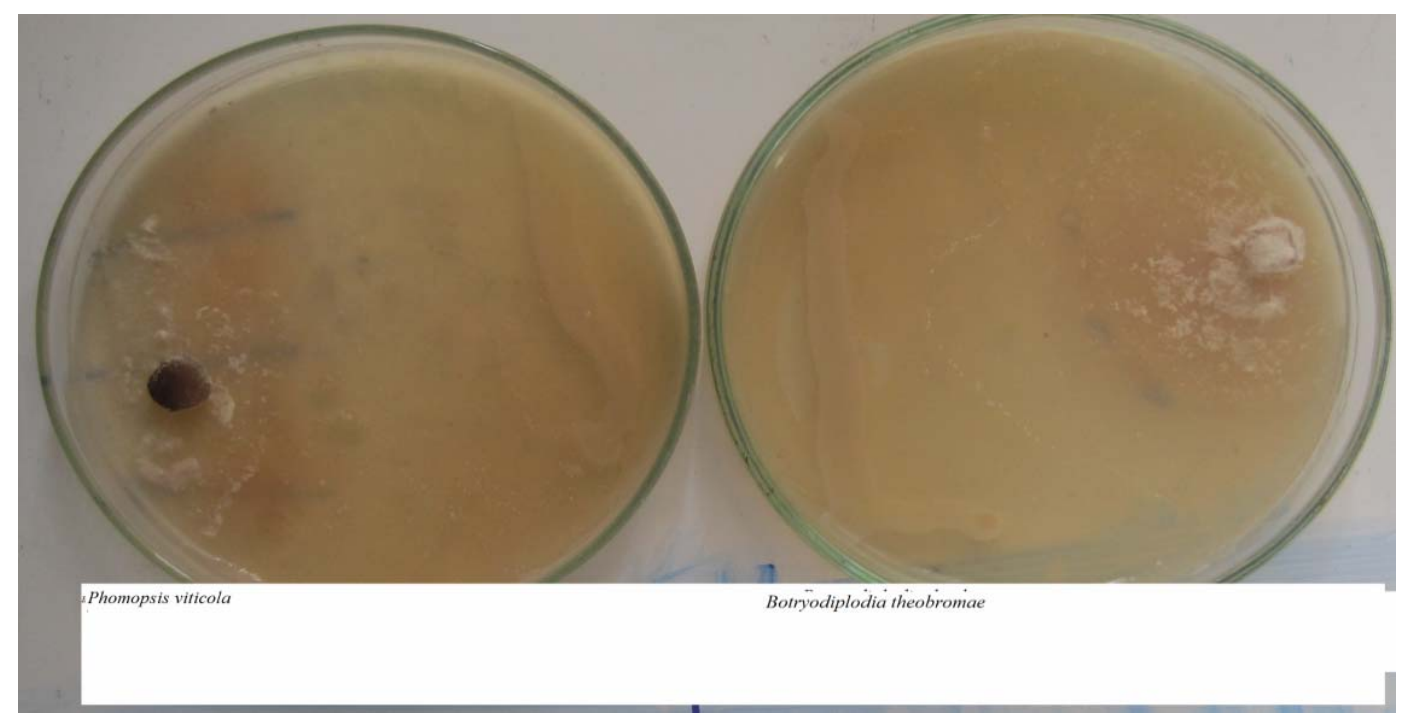

Figure 1. Inhibitory effect of $P$. putida against $B$. theobromae and P. viticola.
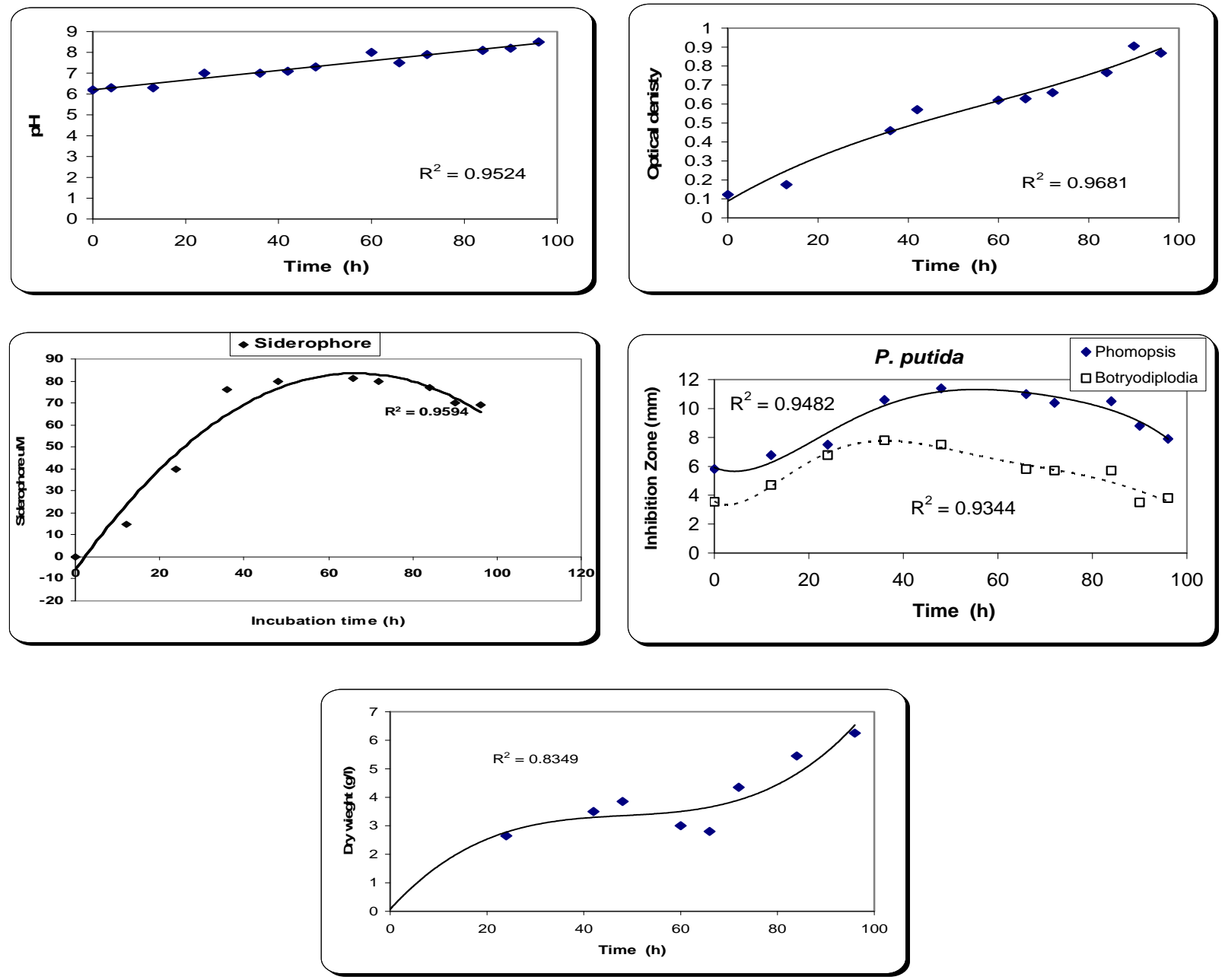

Figure 2. Results of optimization of growth period of $P$. putida.

The zone inhibition of Botryodiplodia, and Phomopsis increased by increasing the glycerol concentration till
$1.5 \% \mathrm{v} / \mathrm{v}$ then decreased (Figure 4). From the previous observations, $1.5 \% \mathrm{v} / \mathrm{v}$ was_chosen as the optimum gly 

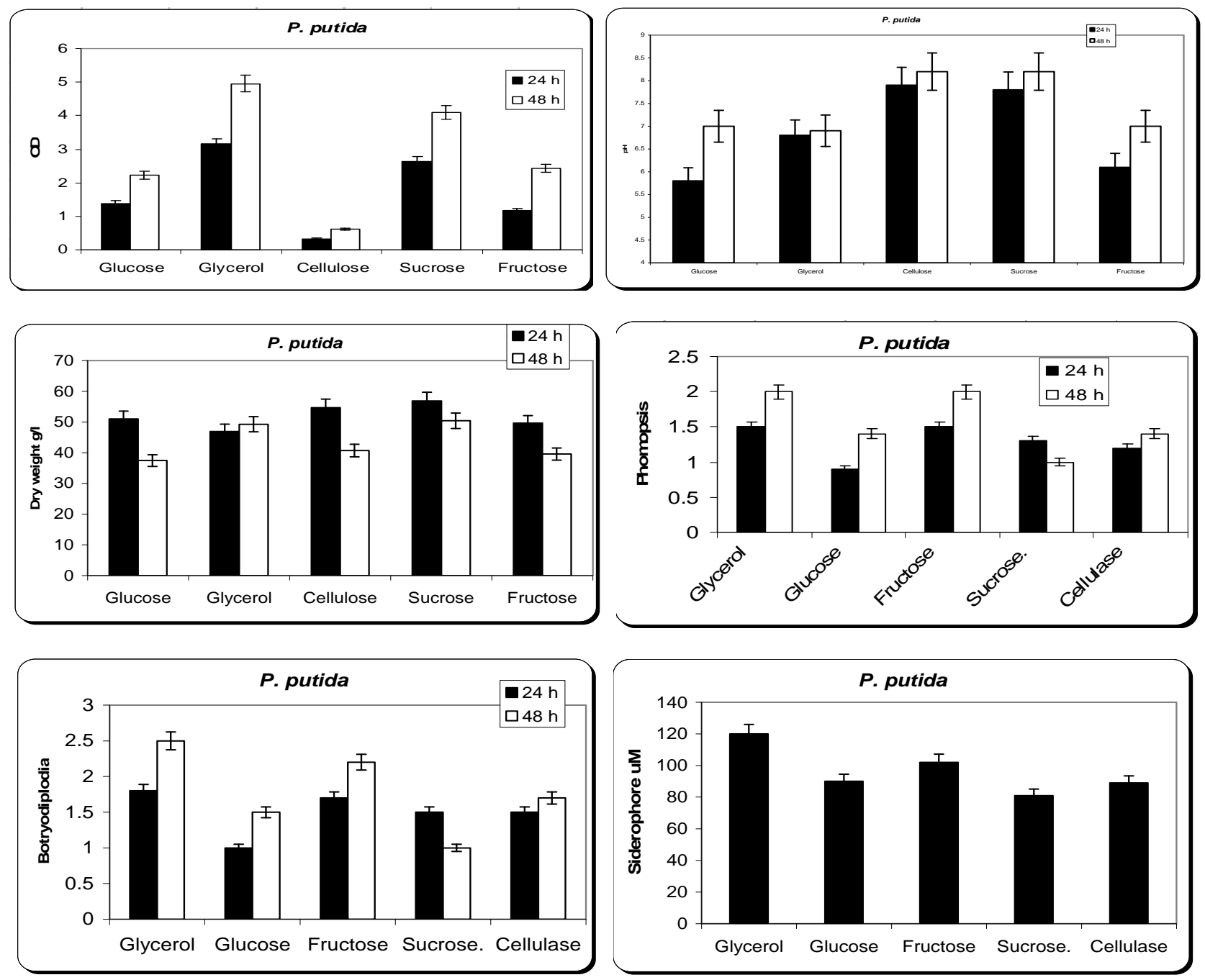

Figure 3. Effect of different carbon source on the growth, inhibition activity and siderophore production.

cerol concentration (Figure 5). The results showed that cell growth and siderophores production were inversely proportional responses Meyer and Abdallah (1978) had previously shown that the amount of pigment synthesized per unit of cell mass was inversely related to the concentration of the factor limiting growth. Siderophores are iron-specific compounds which are secreted under low iron stress and we found that production of siderophores in the medium employed was inversely proportional to the iron concentration in the medium.

By using different types of nitrogen source for the growth of Pseudomonas putida it was noticed that the maximum biomass growth was obtained using yeast extract as nitrogensource. So, the optimum nitrogen source chosen was yeast extract (Figure 6).

\subsection{Formulation}

In general, all formulations had a longer shelf-life at $4^{\circ} \mathrm{C}$ for three months. Analysis of each formulation revealed that glycerol oil at $0.01 \%$ the best oil used for protect $\mathrm{P}$. putida for 3 months in compared with untreated control (Figure 7). In addition, dextran starch and D-glucose at $1 \%$ as sugar sources also gave better effect. However, the other formulation gave high effect in compared with untreated control. So, both glycerol oil plus dextran starch were used in the fermentation and formulation process of P. putida.

\subsection{Field Experiments}

The efficacies of foliar spraying with dry wettable formulation of $P$. putida against die back and dead arm grape diseases under natural conditions were determined in 2011 and 2012 seasons using Flam cultivar in three Governorates (Tables 1 and 2). High significant differences in the percentage of diseases incidence in experiment $(P<0.05)$ were achieved among untreated and treatment with $P$. putida. In vineyards, the alternatives $P$. putida agent provided protection at an important level 

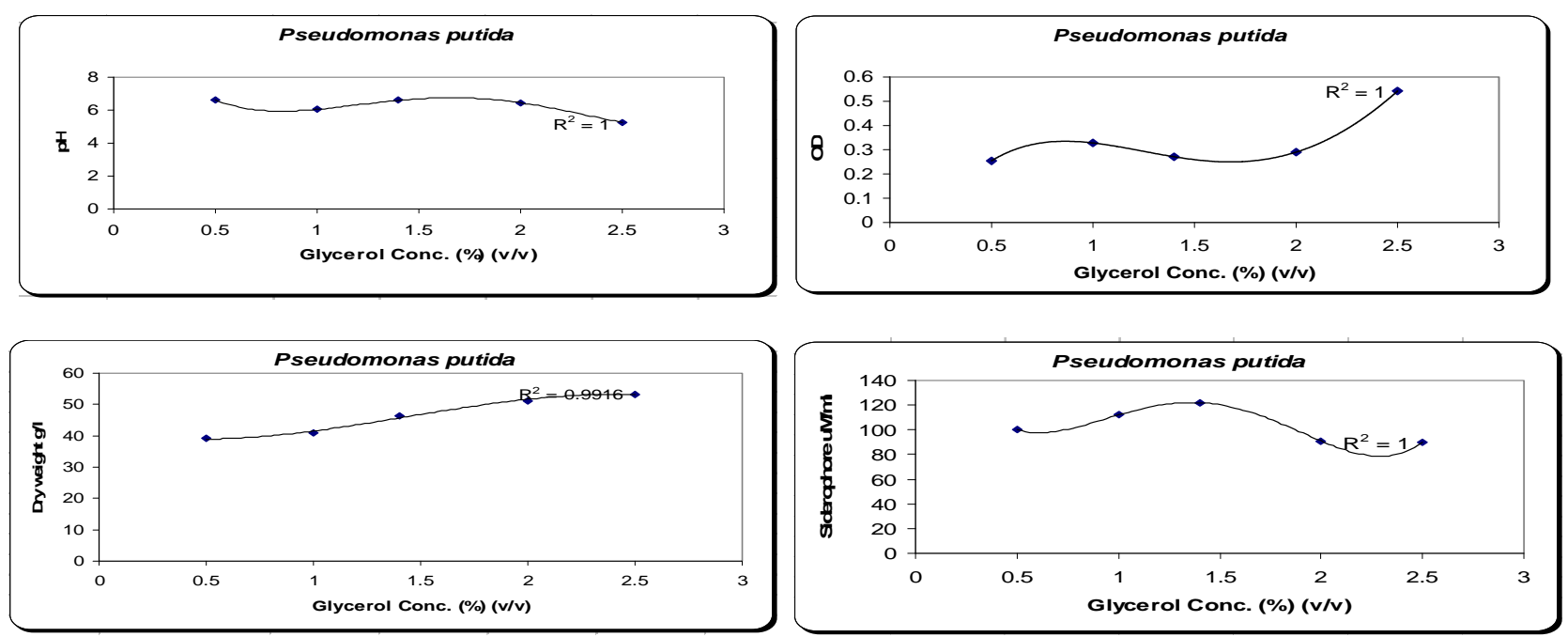

Figure 4. Effect of different carbon concentration on the growth, inhibition activity and siderophore production.

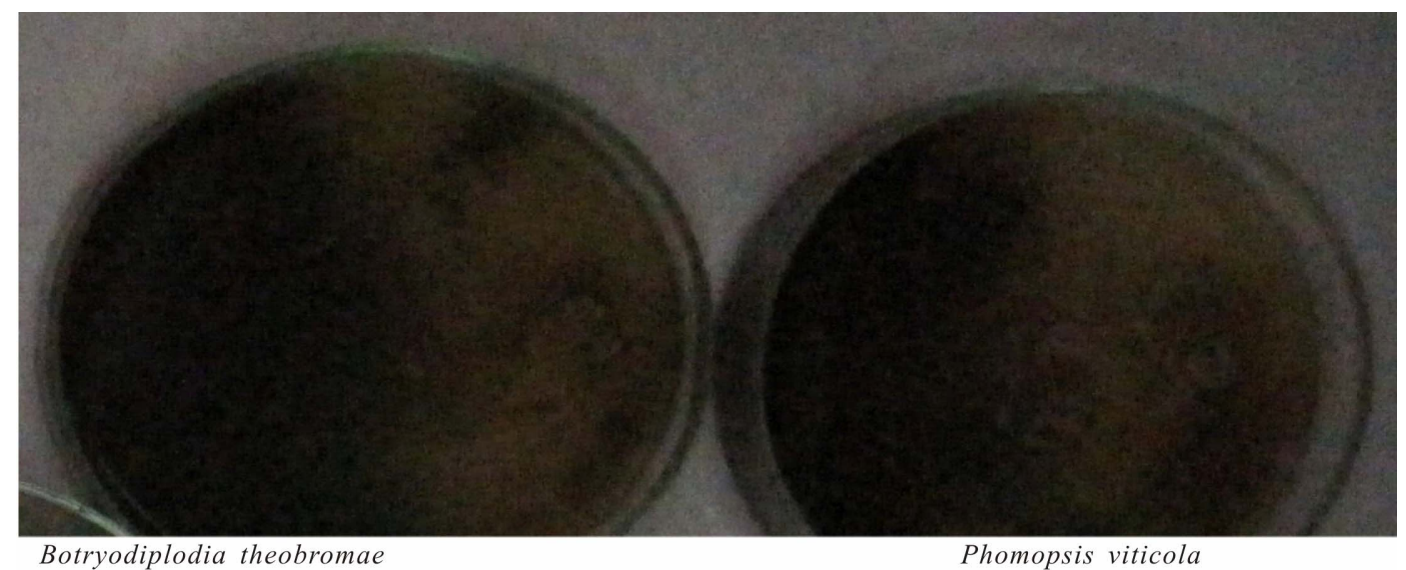

Figure 5. Effect of glycerol as carbon source on Zone inhibition and siderophore production on different solid culture media.

against die back as well as dead arm infection on both leaves and bunches as compared with fungicide or untreated control which records the highest effect (Tables 1 and 2). P. putida completely controlled die back and dead arm (Phomopsis) diseases incidence compared to untreated control and chemical fungicide in both seasons and governorates.

\subsection{Growth Parameters and Yield}

The efficacies of dry wettable formulation of $P$. putida to improve grapevine cv. Flam growth and yield were determined in three regions i.e. Kalubia, Sharkia and Ismailia governorates in seasons 2011 and 2012. Results of Table 3 indicated that, a general increase of total weight of berries/bunch and yield/vine was observed with all treatments than untreated control and fungicide. From the obtained data, (Table 3) the application of $P$. putida was more effective in increasing total weight of berries/ bunch and yield/vine $(\mathrm{kg})$ on grapevine than the fungi- cide and the control.

Concerning the effect of the treatments on the major chemical characteristics from Table 3, it could be noticed that $P$. putida application was more effective in increasing TSS\% and decreased TA $\%$ than fungicide and the control. Finally from the view of the data it could suggested that $P$. putida treatment was more pronounced on the filed application on grapevine by increasing the yield/vine and bunch weight, also with the objective of sense check of the data may be we will neglect some measurement and test others (Figure 8).

Grape (Vitis vinifera) is one of the most economically important fruit crops in the world and has many uses [1]. In general, global agricultural production is under continuous threat due to diseases and as much as $50 \%$ of losses have been attributed to such challenges [10]. These developments are concurrent with the ever growing global population, demanding more food supplies. losses have been attributed to such challenges [10]. 

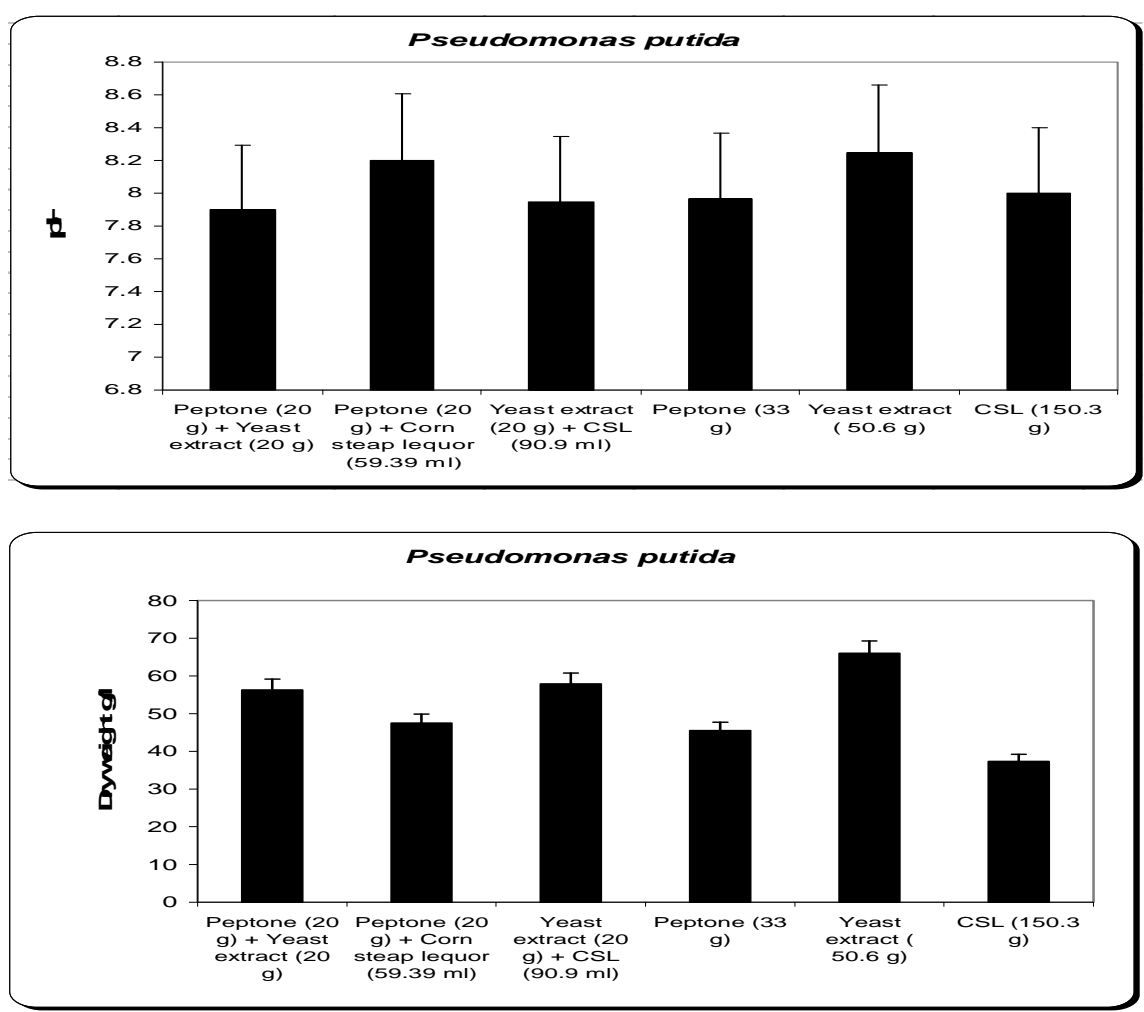

Figure 6. Effect of different nitrogen source on the growth, inhibition activity and siderophore production.

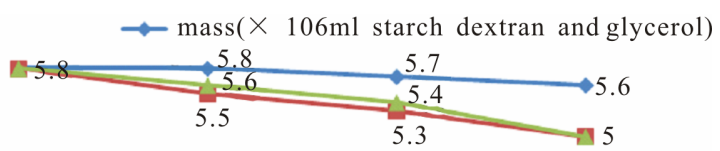

1

2
Mass survival months

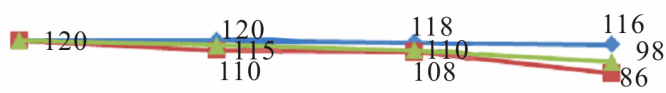

1

2
Siderophore| Months

Figure 7. Effect of different formulation on the survival of $P$. putida during storage periods.

These developments are concurrent with the ever growing global population, demanding more food supplies.

There is therefore an urgent need to develop alternatives to fill this ever increasing gap [8]. Biologically based products were identified as possible alternatives to the address these concerns. This has provided an opportunity for the introduction of microbial products as potential alternatives. It is however essential that the con- tribution of individual isolates constituted in the product is clearly outlined. This is important for purposes of product registration, and the cost implications of their production. Recognition of the environmental factors that regulate the growth and biocontrol efficacy of antagonist bacteria is an essential step towards advancing the level and reliability of their biocontrol potential [15]. The isolation, screening and preservation of potential isolates are the most vital stage, which may determine the success or failure of a putative product. The genus Pseudomonas belongs to the subclass of the Proteobacteria and includes mostly fluorescent Pseudomonads as well as a few non-fluorescent species. P. putida was more effective against die back and phomposis. Their mode of action is extremely varied: they may directly start a lethal biological process or only suppress the bio-aggressor by competition. Sometimes they induce resistance factors in the plant. Many studies involve these bacteria. The broad spectrum nature of the isolate, even though targeted could also have potential negative outcomes.

P. putida as that are able to improve plant growth and plant health and are implicated in the natural supressiveness of plant pathogens [11]. The impact of product application on the microbial product has to be properly investigated prior to product registration. The production technique yielded high spore and cells counts and the isolate was shown to have retained its antifungal proper 
Table 1. Effect of foliar spraying with drywettableformulation of $P$. puita on die back disease of Flam grapevines cultivar.

\begin{tabular}{|c|c|c|c|c|c|c|c|c|c|c|c|c|}
\hline \multirow{3}{*}{ Application } & \multicolumn{4}{|c|}{ Kalubia governorate } & \multicolumn{4}{|c|}{ Sharkia governorate } & \multicolumn{4}{|c|}{ Ismailia governorate } \\
\hline & \multicolumn{2}{|c|}{ Arm infection $\%$} & \multicolumn{2}{|c|}{ Leaf infection \% } & \multicolumn{2}{|c|}{ Arm infection \% } & \multicolumn{2}{|c|}{ Leaf infection $\%$} & \multicolumn{2}{|c|}{ Arm infection \% } & \multicolumn{2}{|c|}{ Leaf infection \% } \\
\hline & 2010 & 2011 & 2010 & 2011 & 2010 & 2011 & 2010 & 2011 & 2010 & 2011 & 2010 & 2011 \\
\hline $\begin{array}{l}\text { Pseudomonas } \\
\text { putida }\end{array}$ & 0.0 & 0.0 & 0.0 & 0.0 & 0.0 & 0.0 & 0.0 & 0.0 & 0.0 & 0.0 & 0.0 & 0.0 \\
\hline Fungicide & 28.7 & 25.8 & 15.5 & 14.8 & 21.4 & 20.9 & 24.6 & 22.9 & 10.3 & 8.9 & 8.5 & 7.9 \\
\hline Water (control) & 63.6 & 55.6 & 43.3 & 32.8 & 65.6 & 61.8 & 49.7 & 46.9 & 49.5 & 45.9 & 18.5 & 16.9 \\
\hline LSD & 12.4 & 11.5 & 9.6 & 8.7 & 10.8 & 9.8 & 11.6 & 10.6 & 8.7 & 6.8 & 6.8 & 5.7 \\
\hline
\end{tabular}

Table 2. Effect of foliar spraying with dry wettable formulation of $P$. puita on dead arm disease of Flam grapevines cultivar.

\begin{tabular}{|c|c|c|c|c|c|c|c|c|c|c|c|c|c|c|c|c|c|c|}
\hline \multirow{3}{*}{ pplication } & \multicolumn{6}{|c|}{ Kalubia governorate } & \multicolumn{6}{|c|}{ Sharkia governorate } & \multicolumn{6}{|c|}{ Ismailia governorate } \\
\hline & \multicolumn{2}{|c|}{$\begin{array}{c}\text { Arm } \\
\text { infection \% }\end{array}$} & \multicolumn{2}{|c|}{$\begin{array}{l}\text { Leaf severity } \\
\quad(0-5)\end{array}$} & \multicolumn{2}{|c|}{$\begin{array}{c}\text { Fruit } \\
\text { infection \% }\end{array}$} & \multicolumn{2}{|c|}{$\begin{array}{c}\text { Arm } \\
\text { infection \% }\end{array}$} & \multicolumn{2}{|c|}{$\begin{array}{l}\text { Leaf severity } \\
\quad(0-5)\end{array}$} & \multicolumn{2}{|c|}{$\begin{array}{c}\text { Fruit } \\
\text { infection \% }\end{array}$} & \multicolumn{2}{|c|}{$\begin{array}{c}\text { Arm } \\
\text { infection \% }\end{array}$} & \multicolumn{2}{|c|}{$\begin{array}{l}\text { Leaf severity } \\
\quad(0-5)\end{array}$} & \multicolumn{2}{|c|}{$\begin{array}{c}\text { Fruit } \\
\text { infection \% }\end{array}$} \\
\hline & 2010 & 2011 & 2010 & 2011 & 2010 & 2011 & 2010 & 2011 & 2010 & 2011 & 2010 & 2011 & 2010 & 2011 & 2010 & 2011 & 2010 & 2011 \\
\hline $\begin{array}{l}\text { Pseudomonas } \\
\text { putida }\end{array}$ & 0.0 & 0.0 & 0.0 & 0.0 & 0.0 & 0.0 & 0.0 & 0.0 & 0.0 & 0.0 & 0.0 & 0.0 & 0.0 & 0.0 & 0.0 & 0.0 & 0.0 & 0.0 \\
\hline Fungicide & 8.9 & 9.9 & 2.3 & 1.8 & 15.1 & 11.8 & 6.6 & 2.7 & 2.6 & 1.8 & 8.3 & 6.9 & 3.6 & 2.8 & 1.6 & 1.3 & 9.4 & 7.8 \\
\hline $\begin{array}{c}\text { Water } \\
\text { (control) }\end{array}$ & 42.8 & 38.8 & 3.5 & 2.5 & 33.7 & 30.6 & 47.9 & 3.6 & 4.3 & 2.8 & 47.5 & 42.6 & 26.6 & 21.8 & 2.6 & 1.7 & 23.6 & 21.9 \\
\hline LSD & 7.5 & 8.6 & 0.7 & 0.8 & 12.5 & 8.7 & 5.4 & 0.6 & 0.8 & 0.6 & 6.5 & 5.4 & 9.5 & 7.6 & 0.9 & 0.8 & 7.8 & 6.8 \\
\hline
\end{tabular}

Table 3. Vine yield and major characteristics of mature bunches of "Flam" grapevine as affected by dry wettable formulation of $P$. puita.

\begin{tabular}{|c|c|c|c|c|c|c|c|c|c|c|c|c|c|c|}
\hline \multirow{3}{*}{ Treatments } & \multicolumn{5}{|c|}{ Kalubia governorate } & \multicolumn{4}{|c|}{ Sharkia governorate } & \multicolumn{5}{|c|}{ Ismailia governorate } \\
\hline & $\begin{array}{c}\text { Total } \\
\text { weight of } \\
\text { berries/ } \\
\text { bunch }(\mathrm{g})\end{array}$ & $\begin{array}{l}\text { Yield/vine } \\
\quad(\mathrm{kg})\end{array}$ & TSS \% & TA & $\%$ & $\begin{array}{c}\text { Total } \\
\text { weight of } \\
\text { berries/ } \\
\text { bunch }(\mathrm{g})\end{array}$ & $\begin{array}{l}\text { Yield/vine } \\
(\mathrm{kg})\end{array}$ & TSS $\%$ & TA $\%$ & $\begin{array}{c}\text { Total } \\
\text { weight of } \\
\text { berries/ } \\
\text { bunch }(\mathrm{g})\end{array}$ & $\begin{array}{l}\text { Yield/vine } \\
(\mathrm{kg})\end{array}$ & TSS $\%$ & & $A \%$ \\
\hline & 20112012 & 20112012 & 20112012 & 2011 & 2012 & 220112012 & 20112012 & 20112012 & 20112012 & 20112012 & 220112012 & 20112012 & 2011 & 12012 \\
\hline Control & 413.3457 .2 & $12.1 \quad 14.7$ & 14.017 .8 & 0.28 & 0.26 & 427.6432. & $113.2 \quad 14.5$ & 16.517 .3 & 0.300 .25 & 467.6476 .1 & 116.217 .6 & 15.716 .8 & 0.34 & 0.37 \\
\hline P. putida & 592.2647 .1 & 23.425 .7 & $19.5 \quad 22.2$ & 0.16 & 0.15 & 627.4654 .5 & $529.2 \quad 32.2$ & 19.722 .3 & 0.260 .20 & 669.4469 .6 & 635.137 .8 & $19.8 \quad 25.7$ & 0.19 & 0.23 \\
\hline Fungicide & 463.1577 .2 & 12.213 .7 & $15.6 \quad 18.7$ & 0.30 & 0.24 & 503.2581. & $816.5 \quad 18.7$ & 17.019 .6 & $0.32 \quad 0.25$ & 503.1521 .8 & 819.522 .9 & $19.2 \quad 21.4$ & 0.38 & 0.33 \\
\hline LSD & 8.4 & $0.7 \quad 1.1$ & $1.4 \quad 1.2$ & 0.8 & 0.7 & 9.7 & 3.2 & $2.3 \quad 2.6$ & $0.3 \quad 0.4$ & $9.4 \quad 11.3$ & 3.6 & $2.1 \quad 2.4$ & 0.8 & 0.9 \\
\hline
\end{tabular}

ties after preservation and bench scale production based on in vitro inhibition of fungi. The media composition should therefore be further investigated and optimized as the recipe used may have cost implications in higher production regimes. For fermentation processing development, recipe development and optimization will form an integral part to ensure a yet economically viable pro0 duction recipe. The mass production systems should be compatible with industrial and commercial development methods and field application. There are two major methods of inoculum production as (a) Solid state fermentation and (b) Liquid state fermentation. Development of formulations with increased shelf life and broad spectrum of action with consistent performance under field conditions could have the way for commercialization of the technology at a faster rate [14]. 


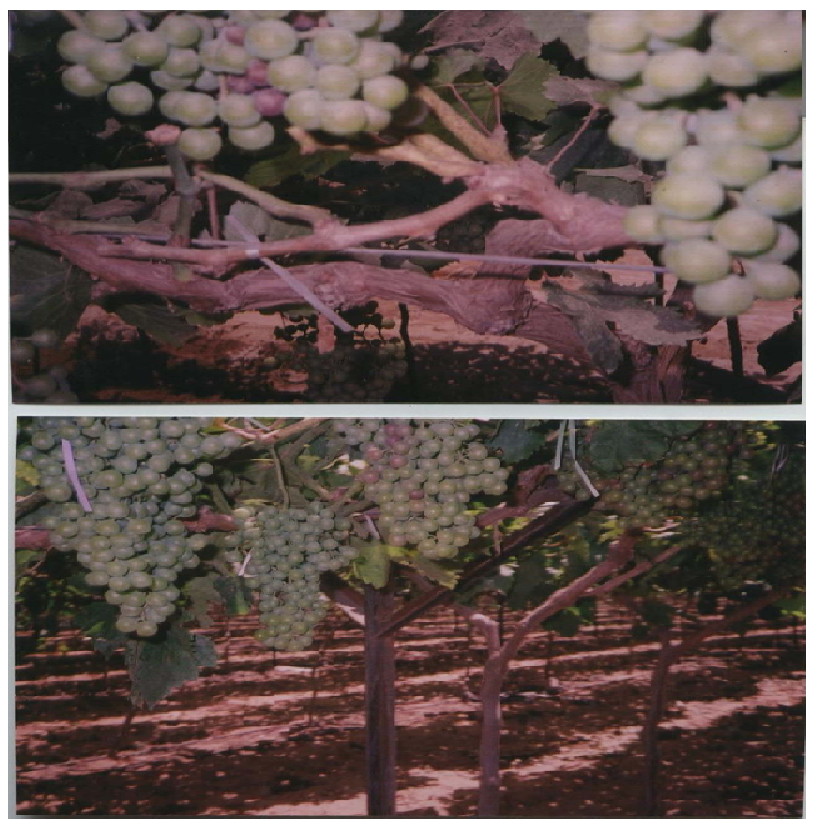

Figure 8. Vine yield of mature bunches of "Flam" grapevine as affected by dry wettable formulation of $P$. puita $(\mathrm{P})$.

Our research studies applying bioproducts become more integrated into management strategies in protection and curative of plant diseases.

This study has shown that antagonist bacteria such as $P$. putida can be produced in different media, using various carbon and nitrogen sources, while maintaining the efficacy as biocontrol of die back and phomposis, with further studies being required to start developing a commercially applicable, environmental-friendly biofungicide for the grapevine crop.

\section{ACKNOWLEDGEMENTS}

This research was supported financially by the Science and Technology Development Fund (STDF), Egypt, Grant No 216 under title: Development of Bioproducts as Bio-fungicides for Controlling of Major Foliar Diseases of Some Economic Horticultural Crops, from 20092012 ; PI. Wafaa M. Haggag.

\section{REFERENCES}

[1] Pearson, R. and Goheen, A. (1998) Compendium of grape diseases.

[2] Van Niekerk, J.M., Fourie, P., Halleen, F. and Crous, P.W. (2006) Botryosphaeria spp. as grapevine trunk disease pathogens. Phytopathologia Mediterranea, 45, S43S54.

[3] Ùrbez-Torres, J.R., Leavitt, G.M., Guerrero, J.C., Guevara, J. and Gubler, W.D. (2008). Identification and pathogenicity of Lasiodiplodia theobromae and Diplodi- aseriata, the causal agents of bot canker disease of grapevines in Mexico. Plant Disease, 92, 519-529. doi:10.1094/PDIS-92-4-0519

[4] Trapman, M., Maxin, P. and Weber, R.W.S. (2007) Diplodiaseriata, cause of black fruit rot in organically grown apples in Holland, Belgium and Northern Germany. http://orgprints.org/13668/

[5] Kaliterna, J., Miličević, T. and Cvjetković, B. (2009). Nove-spoznaje o etiologijicrnepjegavostivinoveloze i taksonomijivrstapovezanih s patogenom Phomopsis viticola (Sacc.) Sacc. [New Insight into Aetiology of Phomopsis Cane and Leaf Spot of Grapevine and Taxonomy of Species Related to Phomopsisviticola (Sacc.) Sacc., in Croatian]. Glasilobiljne Zaštite, 5, 291-295.

[6] Dhanushka, U., Xingzhong, L., McKenzie, E.H.C., Chukeatirote, E., Bahkali, A.H.A. and Hyde, K.D. (2011). The genus Phomopsis: Biology, applications, species concepts and names of common phytopathogens. Fungal Diversity, 50, 189-225. doi:10.1007/s13225-011-0126-9

[7] Rombough, L. (2002) The grape grower, a guide to organic viticulture. Chelsea Green Publishing, 91-92.

[8] Haggag, W.M. (2002) Sustainable agriculture management of plant diseases. Journal of Biological Science, 2, 280- 284.

[9] Haggag, W.M. (2003) Biological control of plant diseases, and its developments. Prospects of the recent agricultural research. The Second Scientific Conference, National Research Center, 45.

[10] Wilson, M. (1997) Biocontrol of aerial plant diseases in agriculture and horticulture: Current approaches and future prospects. Journal of Industrial Microbiology and Biotechnology, 19, 188-191. doi:10.1038/sj.jim.2900436

[11] Meziane, H., Vander Sluis, I., VanLoon, L.C., Hofte, M. and Bakker, P.A.H.M. (2005) Determinants of Pseudomonas putida WCS358 involved in inducing systemic resistance in plants. Molecular Plant Pathology, 6, $177-$ 185. doi:10.1111/j.1364-3703.2005.00276.x

[12] Leeman, M., DenOuden, E.M., VanPelt, J.A., Dirkx, F.P.M., Steijl, H., Bakker, P.A.H.M. and Schippers, B. (1996) Iron availability affects induction of systemic resistance to fusarium wilt of radish by Pseudomonas fluorescens. Phytopathology, 86, 149-155. doi:10.1094/Phyto-86-149

[13] Leeman, M., VanPelt, J.A., DenOuden, F.M., Heinsbroek, M., Bakker, P.A.H.M. and Schippers, B. (1995) Induction of systemic resistance against fusarium wilt of radish by lipopolysaccharides of Pseudomonas fluorescens. Phytopathology, 85, 1021-1027. doi:10.1094/Phyto-85-1021

[14] Vidhyasekaran, P. and Muthamilan, M. (1995) Development of formulations of Pseudomonas fluorescens for control of chickpea wilt. Plant Disease, 79, 782-786. doi:10.1094/PD-79-0782

[15] Duffy, B.K. and Defago, G. (1999) Environmental factors modulating antibiotic and siderophore biosynthesis by Pseudomonas fluorescens biocontrol strains. Applied and Environmental Microbiology, 65, 2429-2438. 